\title{
GROWTH OF Schizolobium amazonicum (Huber ex Ducke) SEEDLINGS INOCULATED WITH ARBUSCULAR MYCORRHIZAL FUNGI
}

\author{
Alyce Vanessa Nunes de Andrade ${ }^{1}$, Jhonata Santos Santana ${ }^{2 *}$, Jeferson Pereira da Silva ${ }^{3}$, Thayllon Ferro \\ Rodrigues da Silva ${ }^{4}$, Yasmim Maria Wolfart Lima ${ }^{5}$, Wilson Araújo da Silva ${ }^{6}$
}

\begin{abstract}
Universidade Estadual da Região Tocantina do Maranhão-UEMASUL, Departamento de Ciências Agrárias, Imperatriz, Maranhão, Brasil e-mail: ${ }^{1}$ alyceflorestal@gmail.com, ${ }^{2 *}$ agro.starf@gmail.com, ${ }^{3}$ jefersonps@msn.com, ${ }^{4}$ thayllonferro@ hotmail.com, ${ }^{5}$ yaswolfart@ gmail.com, ${ }^{6}$ wilsonuemasul@gmail.com
\end{abstract}

Recebido para publicação: 27/12/2017 - Aceito para publicação: 24/07/2019

\begin{abstract}
Resumo
Crescimento de mudas de Schizolobium amazonicum (Huber ex Ducke) inoculadas com fungos micorrízicos arbusculares. Os fungos micorrízicos arbusculares (FMAs) estão presentes em quase todos os solos tropicais ocorrendo em grande número de espécies vegetais, especialmente em plantas arbóreas. A inoculação permite maior rapidez no crescimento das mudas, maior taxa de sobrevivência no viveiro, antecipando o transplante para o campo. Apesar dessas vantagens, existem poucas informações disponíveis a respeito da eficiência obtida da combinação de diferentes espécies micorrízicas. Diante disto, este trabalho teve por objetivo avaliar o desenvolvimento de mudas de Paricá (Schizolobium amazonicum) a partir da associação com diferentes combinações das espécies de FMAs: Rhizoglomus clarus, Claroideoglomus etunicatum e Gigaspora margarita, isoladas e combinadas, em condições de casa de vegetação. O delineamento utilizado foi o inteiramente casualizado, com sete tratamentos e quinze repetições, totalizando cento e cinco unidades experimentais. Foram realizadas três avaliações durante a condução do experimento, aos 30, 60, 90 dias após a semeadura. As variáveis avaliadas foram: altura da planta (H), diâmetro do colo (DC), número de folhas (NF), peso de parte aérea fresca (PPAF), peso de parte aérea seca (PPAS), peso de raiz fresca (PRF), peso de raiz seca (PRS), relação altura/diâmetro (H/D) e Índice de Qualidade de Dickson (IQD). Verificou-se que houve resposta significativa dos tratamentos estudados em nível de 5\% de probabilidade para a maior parte dos parâmetros avaliados. A partir dos resultados obtidos, pode-se concluir que a utilização da inoculação mista Rhizoglomus clarus + Gigaspora margarita apresenta resultados satisfatórios, promovendo melhor desenvolvimento e crescimento nas plantas de Paricá em condições de casa de vegetação.

Palavras-Chave: combinação. espécies micorrízicas. Paricá.
\end{abstract}

\begin{abstract}
Arbuscular mycorrhizal fungi (AMF) occur in large numbers of plant species, especially in tree plants, and are present in almost all tropical soils. Their inoculation enables faster seedling growth and a higher survival rate in the nursery, thereby anticipating the transplant to the field. Despite these advantages, there is little information available on the efficiency obtained from the combination of different mycorrhizal species. In view of this, this work had the objective to evaluate the development of Paricá (Schizolobium amazonicum) seedlings from the association with different combinations of AMF species: Rhizoglomus clarus, Claroideoglomus etunicatum and Gigaspora margarita, isolated and combined under greenhouse conditions. The design was completely randomized, with seven treatments and fifteen replications, totaling one hundred and five experimental units. Three evaluations were carried out during the experiment at 30,60, 90 days after sowing. The evaluated variables were plant height $(\mathrm{H})$, stem diameter (SD), number of leaves (NL), fresh shoot weight (FSW), dry shoot weight (DSW) fresh root weight (FRW), dry root weight (DRW), height/diameter ratio (H/D) and Dickson Quality Index (DQI). It was found that there was a significant response of the treatments studied at a 5\% probability level for most of the evaluated parameters. The results obtained in the present work allowed to conclude that the use of a mixed inoculation of Rhizoglomus clarus + Gigaspora margarita promoted better development and growth in Paricá plants under greenhouse conditions.

Keywords: combination. mycorrhizal species. Paricá.
\end{abstract}

\section{INTRODUCTION}

The Schizolobium amazonicum Huber ex Ducke species, popularly known as Pinho-cuiabano, Paricá, and Bandara (among other common names), is an economically important tree species with wide natural distribution, occurring in the states of Pará and Amazonas, as well as on the border of Peru and Colombia (DUTRA et al. 2017).

Paricá has stood out and conquered its market space among the reforested species in Brazil due to its great economic potential, as it has increases in height and diameter which allow its use in a short period of time, as well

FLORESTA, Curitiba, PR, v. 49, n. 4, p. 651 - 660, out/dez 2019.

Andrade, A. V. N. et.al.

ISSN eletrônico 1982-4688

DOI: $10.5380 /$ rf.v49 i4.57186 
as being as efficient as the exotic Pinus and Eucalyptus species (BIANCHE et al. 2012). According to Iwakiri et al. (2011), its average productivity is around 20 to $30 \mathrm{~m}^{3} / \mathrm{ha} /$ year, showing a Pinus-like productivity of 25 to 30 $\mathrm{m}^{3} \mathrm{ha}^{-1}$ year ${ }^{-1}$, and higher than teak with 15 to $20 \mathrm{~m}^{3} \mathrm{ha}^{-1}$ year-1.

The use of Paricá is an excellent alternative in both silvicultural aspects and in the ability to produce wood with favorable technological characteristics for producing wood laminates and plywood (IWAKIRI et al. 2011). According to ABRAF (2013), the number of Paricá plantations grew significantly in 2012 with 87,901 hectares distributed throughout the states of Pará, Maranhão and Tocantins, with the purpose of producing laminates and plywood, linings, toothpicks/matches, paper, furniture, finishes and frames.

Paricá is a tree with great potential for forestry, so the production of quality seedlings is of great importance to achieve technical and economic viability in establishing forest plantations in degraded areas, reforestation and agroforestry systems (LISBOA et al. 2012).

Arbuscular mycorrhizal fungi (AMFs) exert marked effects on plants through nutritional improvement, increased root production, increased photosynthesis and leaf area, and improved soil aggregation, exerting major influence on plant growth and adaptation to biotic and abiotic soil stresses (COLODETE et al. 2014).

According to Kiers and Van Der Heijden (2006), in over 450 million years of coexistence, fungi and plants have developed elaborate strategies in the ability to communicate molecularly through mechanisms which enable recognition and interaction. The benefits of this association to plants include increased phosphorus and nitrogen uptake, protection against pathogens, and improved drought tolerance; and in return, the host receives carbohydrates and amino acids from the plant to support their growth and reproduction (KIERS; VAN DER HEIJDEN, 2006).

According to Pereira et al. (2012), mycorrhization of native seedlings provides a number of advantages, being recognized for its ability to stimulate plant growth mainly through a greater absorption of nutrients, especially phosphorus, acting with the plant in increasing the tolerance level in adapting to situations of abiotic soil stress. The advantages of mycorrhizal inoculation for growth are diverse and knowledge about the ability of species to form symbioses with these soil fungi is of fundamental importance for reforestation success (COLODETE et al. 2014).

The positive and early effect of inoculation on the growth of native seedlings can contribute to increase their competition and survival, and consequently their establishment in the field. Inoculation is considered an efficient recovery agent for degraded areas (SANTOS et al. 2008).

Although Paricá is a species with excellent timber potential and is widely cultivated in the North and Northeast of the country, there is still a lack of information on its initial development. Thus, the present study aimed to evaluate the benefits provided by inoculating Paricá seedlings with different arbuscular mycorrhizal fungi species under greenhouse conditions and the performance gains provided in the growth and quality parameters of the seedlings in order to verify the real benefits of these fungi on the initial development of seedlings, thus contributing to the success of forestry in the state of Maranhão.

\section{MATERIAL AND METHODS}

The experiment was conducted in a greenhouse at the Technological Diffusion Center (TDC) located in Imperatriz - MA (5 $31^{\circ} 32^{\prime \prime} \mathrm{S}$ and $\left.47^{\circ} 26^{\prime} 35^{\prime \prime} \mathrm{W}\right)$. The climate of the region is classified as (Aw) by the Köppen classification, meaning hot and humid tropical, with a dry winter. The rainy season of Imperatriz extends from November to April, while the least rainy season is from May to October.

The arbuscular mycorrhizal fungi (AMF) used were: Rhizoglomus clarus (CNPAB 005), Claroideoglomus etunicatum (Inoculum 122) and Gigaspora margarita (IES-42) provided by the Johanna Döbereiner Biological Resources Center $(C R B-J D)$, of Embrapa Agrobiology, Seropedic, Rio de Janeiro. Paricá seeds were collected in October 2016 at the Paricá Research Center headquarters field (4 ${ }^{\circ} 18^{\prime} 10.43^{\prime \prime S}$ and $\left.47^{\circ} 33^{\prime} 23.85^{\prime \prime} \mathrm{W}\right)$, located in the municipality of Dom Eliseu, Pará.

The seeds were stored in a cold chamber $\left(10^{\circ} \mathrm{C}\right.$ and $\left.70 \% \mathrm{RH}\right)$ until beginning the work. For asepsis, the seeds were dipped in 5\% sodium hypochlorite solution for $2 \mathrm{~min}$, then washed in running water and placed on paper towels to dry. Overcoming dormancy was accomplished by cutting the integument opposite to the hilum. Next, $22 \times 17 \mathrm{~cm}$ polyethylene pots were used for seedling production along with commercial substrate composed of peat, vermiculite, rice straw, pine bark, coconut straw and nutrients. The substrate used for seedling production was autoclaved for $2 \mathrm{~h}$ at a temperature of $121{ }^{\circ} \mathrm{C}$. The vessels used in the experiment were asepsed with $5 \%$ sodium hypochlorite solution, then rinsed with running water to remove excess sodium hypochlorite and then washed with distilled water and placed to dry in an aseptic environment.

The treatments consisted of inoculations with different AMF species isolated and combined in Paricá seedlings. Forty (40) AMF spores were placed in each pot, and the treatments were: T0 - No inoculation; T1 - 
Inoculation with $R$. clarus, T2 - Inoculation with C. etunicatum, T3 - Inoculation with G. margarita, T4 Inoculation with $R$. clarus and $C$. etunicatum, T5 - Inoculation with $R$. clarus and G. margarita, and T6 Inoculation with $C$. etunicatum and G. margarita. Each treatment consisted of 15 randomized repetitions, totaling 105 experimental units.

The spore powder inoculant was applied to a depth of approximately $2 \mathrm{~cm}$ in the corresponding treatment vessels. They were mixed homogeneously in the substrate, followed by sowing by placing two seeds per pot, and thinning was then performed two weeks after planting when the seedlings had the first pair of newly formed leaves, leaving the most vigorous plant in each pot.

Growth fertilization was started at 15 days with $3 \mathrm{~g} \mathrm{~L}^{-1}$ Simple Super Phosphate, $4 \mathrm{~g} \mathrm{~L}^{-1}$ Urea, $3 \mathrm{~g} \mathrm{~L}^{-1}$ Potassium Chloride and $0.025 \mathrm{~g} \mathrm{~L}^{-1}$ FTE BR $12(7.1 \% \mathrm{Ca} ; 5.7 \% \mathrm{~S} ; 1.8 \% \mathrm{~B} ; 0.8 \% \mathrm{Cu} ; 2.0 \% \mathrm{Mn} ; 0.1 \% \mathrm{Mo}$; and $9.0 \% \mathrm{Zn}$ ) in the proportion of $6 \mathrm{~L}$ of manure to every 1,000 seedlings, thus remaining until the end of the experiment at 90 days, according to the recommendations of Wendling et al. (2011) for native forest species. The seedlings were grown in a greenhouse with shading of $50 \%$ and automatic drip irrigation with two irrigations a day at $05 \mathrm{~h}$ and $17 \mathrm{~h}$, with each irrigation lasting $5 \mathrm{~min}$.

Plant development was evaluated every 30 days by measuring the following morphological variables: height $(\mathrm{H})$ between the substrate level until the apical region; stem diameter (SD) at $0.5 \mathrm{~cm}$ from the ground; number of leaves (NL) and the height and diameter ratio (H/D). This procedure was performed at 30, 60 and 90 days after planting. The collection at the end of the experiment was performed by cutting the root and shoot with the help of pruning shears.

Next, the following variables were observed for each experimental unit: fresh shoot weight (FSW), dry shoot weight (DSW), fresh root weight (FRW), dry root weight (DRW) and root volume (RV). A precision scale was used for weighing and the root system volume was estimated by the water level displacement in a graduated beaker.

The Dickson Quality Index (DQI) was subsequently determined from these analyzes as a function of shoot height (H), stem diameter (SD), dry shoot weight (DSW) and dry root weight (DRW) using the equation described below:

$$
\mathrm{DQI}=\frac{\mathrm{TDW}(\mathrm{g})}{\mathrm{H}(\mathrm{cm}) / \mathrm{SD}(\mathrm{mm})+\mathrm{SDW}(\mathrm{g}) / \mathrm{DRW}(\mathrm{g})}
$$

In which: TDW is total dry weight $(\mathrm{g}), \mathrm{H}$ is height $(\mathrm{cm}), \mathrm{SD}$ is stem diameter $(\mathrm{mm}), \mathrm{SDW}$ is the shoot dry weight $(\mathrm{g})$ and DRW is dry root weight $(\mathrm{g})$. Total dry weight (TDW) was obtained by the sum of SDW and RDW.

An analysis of variance was performed for each of the variables evaluated in the experiment using the ASSISTAT 7.7 statistical program. The Tukey test was applied at 5\% probability level after normality and data homogeneity tests by different methods.

\section{RESULTS}

From the analysis of variance it was found that there was a significant response to inoculation with AMF for the following evaluated variables: number of leaves (NL), plant height $(\mathrm{H})$, stem diameter (SD), height/ diameter ratio (H/D), fresh shoot weight (FSW), dry shoot weight (DSW) and Dickson Quality Index (DQI), with no significant effect for fresh root weight (FRW), dry root weight (DRW) and root volume (RV).

The treatments using the combinations of the R. clarus $+C$. etunicatum and $R$. clarus + G. margarita species in relation to the control presented higher average values for most of the evaluated variables, except for the height/stem diameter ratio (H/D), for which where the $R$. clarus isolate stood out (Tables 1, 2, 3 and 4).

For the number of leaves (NL) at 30 and 60 days, the mixed inoculum (R. clarus $+G$. margarita) and $(R$. clarus $+C$. etunicatum) presented the highest averages (Table 1), and the plants inoculated with the mixed inoculum ( $R$. clarus + G. margarita) also remained with the largest number of leaves in the data collected at 90 days, being $71.43 \%$ larger than the control.

Tabela 1. Valores médios de número de folhas obtidos pelos sete tratamentos em mudas de Schizolobium amazonicum (Huber ex Ducke) aos 30, 60 e 90 dias após a instalação do experimento em casa de vegetação.

Table 1. Mean values of number of leaves obtained by seven treatments applied to Schizolobium amazonicum (Huber ex Ducke) seedlings at 30,60 and 90 days after installing the experiment in a greenhouse.

FLORESTA, Curitiba, PR, v. 49, n. 4, p. 651 - 660, out/dez 2019. 


\begin{tabular}{cccc}
\hline & Number of leaves & & \\
Treatments & 30 Days & 60 Days & 90 Days \\
\hline Control & $1.3 \mathrm{~b}$ & $3.1 \mathrm{~b}$ & $3.5 \mathrm{~b}$ \\
R. clarus & $2.1 \mathrm{ab}$ & $3.9 \mathrm{ab}$ & $4.2 \mathrm{ab}$ \\
C. etunicatum & $2.3 \mathrm{a}$ & $3.4 \mathrm{ab}$ & $5.4 \mathrm{ab}$ \\
G. margarita & $1.9 \mathrm{ab}$ & $3.3 \mathrm{~b}$ & $4.5 \mathrm{ab}$ \\
R. clarus + C. etunicatum & $2.7 \mathrm{a}$ & $4.3 \mathrm{ab}$ & $5.7 \mathrm{a}$ \\
R. clarus + G. margarita & $2.7 \mathrm{a}$ & $4.9 \mathrm{a}$ & $6.0 \mathrm{a}$ \\
C. etunicatum + G. margarita & $2.3 \mathrm{a}$ & $3.9 \mathrm{ab}$ & $5.3 \mathrm{ab}$ \\
\hline CV\% & 37.0 & 36.0 & 37.8 \\
\hline
\end{tabular}

Legend: $R$. clarus = Rhizoglomus clarus, C. etunicatum = Claroideoglomus etunicatum, G. margarita = Gigaspora margarita .

$\mathrm{CV}$, Coefficient of variation. Means followed by the same letter in the columns do not differ statistically by the Tukey Test at $5 \%$ probability.

For height $(\mathrm{H})$ at 30 days, the mixed inoculum of $R$. clarus $+G$. margarita and $R$. clarus presented higher averages than inoculation with $C$. etunicatum $+G$. margarita, although these were not different from the control; moreover, at 90 days the plants inoculated with $R$. clarus, $R$. clarus $+G$. margarita, followed by $R$. clarus $+C$. etunicatum inoculum showed $55.50 \%, 59.48 \%$ and $57.61 \%$ increments, respectively, when compared to the control (Table 2).

Tabela 2. Valores médios da altura de plantas obtidos pelos sete tratamentos em mudas de Schizolobium amazonicum (Huber ex Ducke) aos 30, 60 e 90 dias após a instalação do experimento em casa de vegetação.

Table 2. Mean plant height values obtained by seven treatments applied to Schizolobium amazonicum (Huber ex Ducke) seedlings at 30,60 and 90 days after installing the experiment in a greenhouse.

\begin{tabular}{|c|c|c|c|}
\hline \multicolumn{4}{|c|}{ Height $(\mathrm{cm})$} \\
\hline Treatments & 30 Days & 60 Days & 90 Days \\
\hline Control & $21.6 \mathrm{abc}$ & $32.8 \mathrm{ab}$ & $42.7 \mathrm{~b}$ \\
\hline R. clarus & $27.8 \mathrm{ab}$ & $36.4 \mathrm{ab}$ & $66.4 \mathrm{a}$ \\
\hline C. etunicatum & $23.8 \mathrm{abc}$ & $31.9 \mathrm{ab}$ & $56.1 \mathrm{ab}$ \\
\hline G. margarita & $20.2 \mathrm{bc}$ & $27.3 \mathrm{~b}$ & $54.8 \mathrm{ab}$ \\
\hline R. clarus + C. etunicatum & $23.3 \mathrm{abc}$ & $35.5 \mathrm{ab}$ & $67.3 \mathrm{a}$ \\
\hline R. clarus + G. margarita & $28.8 \mathrm{a}$ & $39.4 \mathrm{a}$ & $68.1 \mathrm{a}$ \\
\hline C. etunicatum + G. margarita & $18.9 \mathrm{c}$ & $27.4 \mathrm{~b}$ & $56.3 \mathrm{ab}$ \\
\hline CV\% & 30.9 & 26.9 & 26.5 \\
\hline
\end{tabular}

Legend: $R$. clarus = Rhizoglomus clarus, C. etunicatum = Claroideoglomus etunicatum, G. margarita = Gigaspora margarita.

$\mathrm{CV}$, Coefficient of variation. Means followed by the same letter in the columns do not differ statistically by the Tukey Test at $5 \%$ probability.

Regarding stem diameter (SD) in the data collected at 90 days, mycorrhized seedlings with mixed inoculum of $R$. clarus $+G$. margarita species presented higher means than the C. etunicatum and G. margarita isolates, although it was not statistically different from the control group.

Tabela 3. Valores médios de diâmetro do colo obtidos pelos sete tratamentos em mudas de Schizolobium amazonicum (Huber ex Ducke) aos 30, 60 e 90 dias após a instalação do experimento em casa de vegetação.

Table 3. Mean stem diameter values obtained by seven treatments applied to Schizolobium amazonicum (Huber ex Ducke) seedlings at 30,60 and 90 days after installing the experiment in a greenhouse. 


\begin{tabular}{cccc}
\hline & Stem diameter $(\mathrm{mm})$ & & \\
Treatments & 30 Days & 60 Days & 90 Days \\
\hline Control & $3.5 \mathrm{abc}$ & $5.1 \mathrm{ab}$ & $7.8 \mathrm{abc}$ \\
R. clarus & $3.8 \mathrm{ab}$ & $5.6 \mathrm{a}$ & $7.7 \mathrm{abc}$ \\
C. etunicatum & $2.9 \mathrm{c}$ & $4.5 \mathrm{ab}$ & $6.9 \mathrm{bc}$ \\
G. margarita & $3.1 \mathrm{bc}$ & $4.2 \mathrm{~b}$ & $6.4 \mathrm{c}$ \\
R. clarus + C. etunicatum & $4.0 \mathrm{a}$ & $5.6 \mathrm{a}$ & $8.8 \mathrm{ab}$ \\
R. clarus + G. margarita & $3.8 \mathrm{ab}$ & $5.6 \mathrm{a}$ & $9.4 \mathrm{a}$ \\
C. etunicatum + G. margarita & $3.6 \mathrm{abc}$ & $4.9 \mathrm{ab}$ & $7.6 \mathrm{abc}$ \\
\hline CV\%* & 22.2 & 24.7 & 26.0 \\
\hline
\end{tabular}

Legend: $R$. clarus = Rhizoglomus clarus, C. etunicatum = Claroideoglomus etunicatum, G. margarita = Gigaspora margarita .

$\mathrm{CV}$, Coefficient of variation. Means followed by the same letter in the columns do not differ statistically by the Tukey Test at $5 \%$ probability.

In Figure 1, seedlings inoculated with R. clarus + C. etunicatum and $R$. clarus at 90 days presented the highest H/D averages, differing significantly from the Control by $55.04 \%$ and $70.35 \%$ higher, respectively.

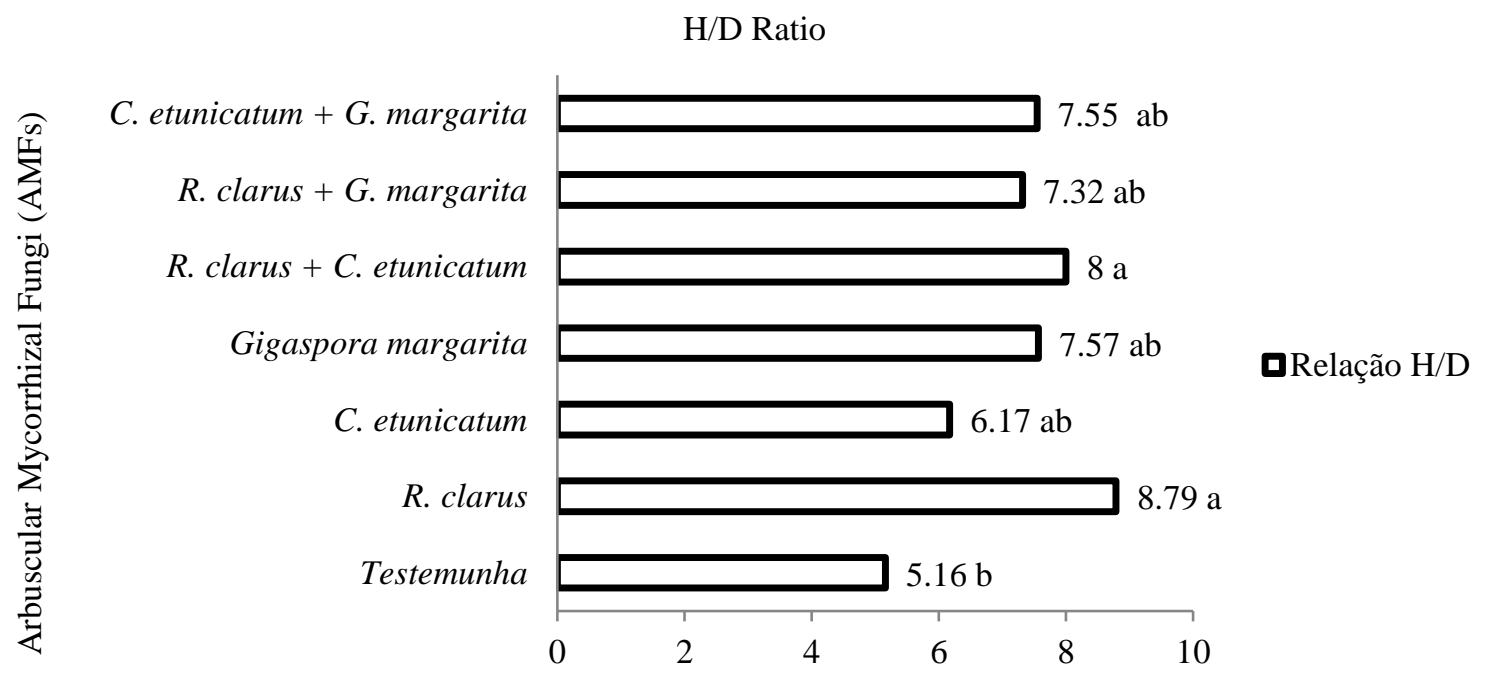

Legend: $R$. clarus $=$ Rhizoglomus clarus, C. etunicatum = Claroideoglomus etunicatum, G. margarita = Gigaspora margarita . Means followed by the same letter in the columns do not differ statistically by the Tukey Test at $5 \%$ probability.

Figura 1. Médias da altura/diâmetro obtidos pelos sete tratamentos em mudas de Schizolobium amazonicum (Huber ex Ducke) aos 90 dias após a instalação do experimento em casa de vegetação.

Figure 1. Mean of height/diameter obtained by seven treatments applied to Schizolobium amazonicum (Huber ex Ducke) seedlings at 90 days after installing the experiment in a greenhouse.

It was found that the $R$. clarus + G. margarita mixed treatment differed from the others for dry shoot weight (DSW) and fresh shoot weight (FSW), being $233.57 \%$ and $186.61 \%$ higher than the control, respectively (Table 4); a fact that confirms the efficiency of the fungal combination.

Dry root weight (DRW) and fresh root weight (FRW) did not differ by Tukey test at 5\% probability. The inoculated plants did not differ in relation to the control for the DRW variable. Similar results were obtained for fresh root weight (FRW), since the inoculated plants also did not differ in relation to the control (Table 4).

Furthermore, the results for root volume (RV) showed no significant difference, so the inoculated plants did not obtain significant increments in relation to the control (Table 4).

FLORESTA, Curitiba, PR, v. 49, n. 4, p. 651 - 660, out/dez 2019.

Andrade, A. V. N. et.al.

ISSN eletrônico 1982-4688

DOI: $10.5380 /$ rf.v49 i4.57186 
Tabela 4. Valores médios de peso de parte aérea seca (PPAS), peso de parte aérea fresca (PPAF), peso de raiz seca (PRS), peso de raiz fresca (PRF) e volume de raiz (VOL) obtidos pelos sete tratamentos em mudas de Schizolobium amazonicum (Huber ex Ducke) aos 90 dias após a instalação do experimento em casa de vegetação.

Table 4. Mean values of dry shoot weight (DSW), fresh shoot weight (FSW), dry root weight (DRW), fresh root weight (FRW) and root volume (RV) obtained by seven treatments applied to Schizolobium amazonicum (Huber ex Ducke) seedlings at 90 days after installing the experiment in a greenhouse.

\begin{tabular}{cccccc}
\hline Treatments & $\begin{array}{c}\text { DSW } \\
(\mathrm{g})\end{array}$ & $\begin{array}{c}\text { FSW } \\
(\mathrm{g})\end{array}$ & $\begin{array}{c}\text { DRW } \\
(\mathrm{g})\end{array}$ & $\begin{array}{c}\text { FRW } \\
(\mathrm{g})\end{array}$ & $\begin{array}{c}\text { RV } \\
\left(\mathrm{m}^{3}\right)\end{array}$ \\
\hline Control & $14.0 \mathrm{~b}$ & $43.3 \mathrm{~b}$ & $7.3 \mathrm{a}$ & $21.3 \mathrm{a}$ & $25.0 \mathrm{a}$ \\
R. clarus & $16.0 \mathrm{~b}$ & $53.0 \mathrm{~b}$ & $6.7 \mathrm{a}$ & $31.0 \mathrm{a}$ & $33.0 \mathrm{a}$ \\
C. etunicatum & $14.3 \mathrm{~b}$ & $43.7 \mathrm{~b}$ & $6.5 \mathrm{a}$ & $24.7 \mathrm{a}$ & $26.7 \mathrm{a}$ \\
G. margarita & $17.0 \mathrm{~b}$ & $52.3 \mathrm{~b}$ & $5.7 \mathrm{a}$ & $28.7 \mathrm{a}$ & $27.3 \mathrm{a}$ \\
R. clarus + C. etunicatum & $21.7 \mathrm{~b}$ & $67.0 \mathrm{~b}$ & $8.0 \mathrm{a}$ & $35.0 \mathrm{a}$ & $31.3 \mathrm{a}$ \\
R. clarus + G. margarita & $46.7 \mathrm{a}$ & $124.1 \mathrm{a}$ & $8.7 \mathrm{a}$ & $28.3 \mathrm{a}$ & $31.3 \mathrm{a}$ \\
C. etunicatum + G. margarita & $20.0 \mathrm{~b}$ & $61.3 \mathrm{~b}$ & $5.7 \mathrm{a}$ & $31.7 \mathrm{a}$ & $30.7 \mathrm{a}$ \\
\hline CV\% & 64.4 & 59.7 & 47.9 & 45.2 & 44.4 \\
\hline
\end{tabular}

Legenda: $R$. clarus = Rhizoglomus clarus, $C$. etunicatum = Claroideoglomus etunicatum, G. margarita = Gigaspora margarita .

$\mathrm{CV}$, Coefficient of variation. Means followed by the same letter in the columns do not differ statistically by Tukey test at $5 \%$ probability.

The Dickson Quality Indexes (DQI) are presented in Figure 2, where it is verified that there were significant differences in the quality of Paricá seedlings as a function of the treatments used. Note that the R. clarus + G. margarita mixed treatment presented the highest DQI.

Dickson Quality Index (DQI)

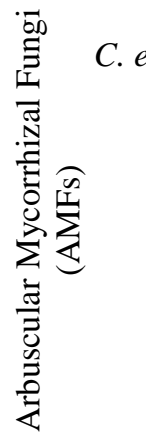

$$
\begin{array}{r}
\text { etunicatum }+ \text { G. margarita } \\
R . \text { clarus }+ \text { G. margarita } \\
R . \text { clarus }+ \text { C. etunicatum } \\
\text { Gigaspora margarita } \\
\text { C. etunicatum } \\
\text { R. clarus } \\
\text { Testemunha }
\end{array}
$$

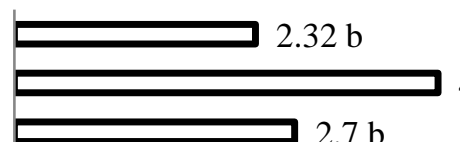

4,08 a

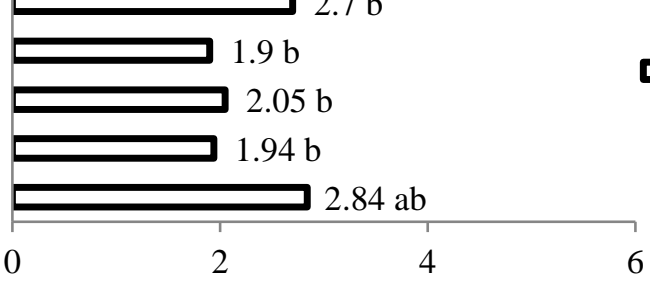

口Índice de qualidade

de Dickson (IQD)

Legend: $R$. clarus = Rhizoglomus clarus, C. etunicatum = Claroideoglomus etunicatum, G. margarita = Gigaspora margarita . Means followed by the same letter in the columns do not differ statistically by Tukey test at $5 \%$ probability.

Figura 2. Médias dos índices de Qualidade de Dickson (IQD) obtidos pelos sete tratamentos em mudas de Schizolobium amazonicum (Huber ex Ducke) aos 90 dias após a instalação do experimento, sob diferentes tratamentos em casa de vegetação.

Figure 2. Mean of Dickson Quality Indexes (DQI) obtained by seven treatments applied to Schizolobium amazonicum (Huber ex Ducke) seedlings at 90 days after installing the experiment in a greenhouse.

\section{DISCUSSION}

Inoculated plants presented a higher number of leaves than the control and the increase in the number of leaves is usually related to a larger leaf area, and the larger the leaf area, the larger the light interception surface which results in higher photosynthetic rates and higher accumulation of dry matter (SANQUETTA et al. 2014). The results found in this study corroborate those of Santos et al. (2008), who obtained larger leaf area due to mycorrhization in native species. 
Regarding plant height, inoculation with $R$. clarus, $R$. clarus + C. etunicatum and R. clarus + G. margarita isolates stood out from other treatments, especially at 90 days. The averages found are above the values proposed by Gomes et al. (2002) for native forest species, who consider that the ideal seedling has a height between 20 and $35 \mathrm{~cm}$, and the height of Paricá seedlings at 90 days ranged from 18 to $68 \mathrm{~cm}$ with normal growth and no estiolation symptoms.

From these results, it is noted that the mixed inoculation of mycorrhizal fungi in S. amazonicum seedlings can be considered an advantageous strategy in commercially cultivating $S$. amazonicum, since the rapid gain in height in the first months after planting is critical to the plant's success under field conditions. Mixed inoculation using two or more AMF species is a great alternative to evaluate the possible existence of a synergistic effect of inoculation, which may result in increased efficiency which outweighs the productive benefits obtained with them when used in isolation. Thus, different combinations of AMF species should be tested on the same plant under the same environmental conditions to select efficient combinations for their ability to promote better vegetative development, as well as nutritional and phytosanitary quality to their host.

It is noteworthy that the use of larger seedlings which had growth induced by arbuscular mycorrhizal fungi do not pose risks to the establishment and initiating of planting, since they still have good vigor of vegetative and root system growth in perfect condition with no problems of root malformation due to the folding caused by the physical restriction of the container volume.

The results found in this study at 90 days with the use of $R$. clarus, $R$. clarus $+C$. etunicatum and $R$. clarus + G. margarita corroborate those obtained by Boff et al. (2014), who also found that mixed inoculation with $R$. clarus + G. margarita was able to promote higher growth in Paricá seedlings compared to the control. Lucena et al. (2013) also found that the height of Paricá plants inoculated with native arbuscular mycorrhizal fungi spores grown in a greenhouse was significantly higher when compared to the control group and chemically fertilized plants.

Although the mixed inoculum of $R$. clarus $+G$. margarita species presented better performance than $C$. etunicatum and G. margarita isolates, it did not differ in relation to the control. The results found for (SD) were different from those observed by Brito et al. (2017), who obtained an increase of $15.7 \%$ with the mixed treatment of $R$. clarus + G. margarita in relation to the control, in addition to the significant difference. According to Gomes and Paiva (2004), significant diameter values should be obtained for better shoot development stability. Thus, nutrient uptake and translocation between the different organs of the seedlings is facilitated.

The height/stem diameter ratio (H/D) is an important variable in seedling quality evaluation because it reflects characteristics such as accumulation of reserves, greater resistance and better fixation to the soil. According to Araújo et al. (2016), seedlings with low stem diameter and high heights are considered of inferior quality in relation to smaller heights with a larger stem diameter. Moreover, according to Gomes and Paiva (2004), measuring stem diameter alone or combined with height is one of the best attributes for assessing seedling quality, because the larger the diameter, the better the growth balance with the shoot, especially when seedling rustification is required. José et al. (2009) suggest that the result of this division of height (H) by diameter (D) should be less than 10 for forest species. Considering these limits for the results obtained in this study, the seedlings have a good quality standard since the mean height/stem diameter values obtained in this study are lower than the minimum limit.

Based on the data presented in Table 4, it was possible to notice that the mixed treatment of R. clarus + G. margarita significantly affected the dry shoot weight (DSW) and fresh shoot weight (FSW), which confirms the higher efficiency of developing $S$. amazonicum seedlings when the combination of these fungi was used. The conclusions of Boff et al. (2014) corroborate the results obtained in this study, as they also observed higher biomass with the use of R. clarus and G. margarita in Paricá plants, attributing the higher dry biomass in seedlings to the increase in nutrient acquisition provided by mixed inoculation.

There was no significant difference regarding the dry root weight (DRW) and fresh root weight (FRW) variables, so the plants inoculated with the arbuscular mycorrhizal fungi did not show significant increases in relation to the control and thereby did not evidence a positive influence of these combinations on the control of root development in relation to uninoculated plants. Different results to those obtained in this study were found by Samarão et al. (2011), who found that inoculation with Glomus clarum and G. margarita fungal species in soursop (Annona muricata) seedlings provided linear increases in shoot and root dry matter yield, while uninoculated seedlings did not respond to treatments.

FLORESTA, Curitiba, PR, v. 49, n. 4, p. 651 - 660, out/dez 2019. 
According to Lacerda et al. (2011), for the seedlings to be used in reforestation, it is essential that they are of good quality and present an increase in the root production in order to ensure their establishment in the field. Greater development of the root system gives the plant greater nutrient and water absorption capacity, and serves as a source of nutrient reserve for the plant, as well as better support and survivability after being transplanted into the field (SOARES et al. 2003).

Regarding the root system volume (RV), it was noted that there was no significant difference for any of the studied treatments up to 90 days of observation, therefore not demonstrating a positive influence of these combinations on the increase in the root system volume in relation to the non-inoculated plants.

The results found in this study for the root system volume (RV) parameter do not corroborate those reported by Soares et al. (2012), who affirm that the root volume of seedlings submitted to AMF inoculation is higher when compared to non-inoculated seedlings. In this regard, Sugai et al. (2010) described that increasing the volume and extension of the root system is of great importance in the production of seedlings for reforestation in degraded or low fertility sites, as it provides more resistant plants with better conditions for water and nutrient absorption and survival capacity in the field after planting.

Although the application of AMF did not change the root-related variables, the significant responses obtained for the other variables such as: height $(\mathrm{H})$, number of leaves $(\mathrm{NL})$, height/stem diameter ratio (H/D), dry shoot weight (DSW) and fresh shoot weight (FSW) of the inoculated plants in relation to the control indicate the occurrence of symbiosis and the advantages of using AMFs in producing Paricá seedlings.

Another important variable is the Dickson Quality Index (DQI), which according to Fonseca et al. (2002) is one of the best seedling quality indexes considering the robustness and equilibrium of seedling biomass distribution in the calculation, in which a higher index represents a better quality seedling. Thus, the higher the DQI value, the higher the seedling survival rate, as these seedlings will generally have higher values of SD, DSW, DRW and TDW. The DQI averages ranged from 1.90 for the G. margarita fungus species to 4.08 for the $R$. clarus + G. margarita mixed inoculation, indicating that the plants inoculated with this last treatment are of superior quality as this indicator is considered quite complete because it lists several important parameters for seedling quality evaluation.

It was possible to observe that there was a gradual increase in the studied variables simultaneously to the growth of the plants, which proves that the longer the exposure time of the fungus with the host root, the greater the benefits to the plant will be (COLODETE et al. 2014). Given this, it is possible to emphasize that quality seedlings inoculated with arbuscular mycorrhizal fungi are a viable agroecological alternative to maximize sustainable production of native species such as Paricá.

\section{CONCLUSIONS}

- There were benefits in the use of arbuscular mycorrhizal fungi in most of the evaluated variables (NL, H, H/D, DSW, FSW and DQI), contributing to the production of higher quality seedlings.

- The seedlings inoculated with AMF showed higher growth in relation to the control, especially inoculation with mixed inoculum ( $R$. clarus $+G$. margarita)

- The inoculation of arbuscular mycorrhizal fungi becomes a viable practice to be incorporated into the Paricá seedling production process in the southwest of Maranhão state.

\section{REFERENCES}

ABRAF. ASSOCIAÇÃO BRASILEIRA DE FLORESTAS PLANTADAS. Anuário estatístico ABRAF 2013 ano base 2012. Brasília, 2013. < http://www.ipef.br/estatisticas/relatorios/anuario-abraf13-br.pdf> Acesso em: 01 dez. 2017.

ARAÚJO, E.C.; COSTA, R.S.; LOPES, E.C.; DAHER, R.F.; FERNANDES, M.E.B. Qualidade das mudas de espécies arbóreas de mangue cultivadas em viveiro e diferentes substratos. Revista Acta Ambiental Catarinense, v.11 n.1/2 p. 21-32, 2016.

BIANCHE, J.J.; CARNEIRO, J. C.O; VITAL, B.R; PEREIRA, F.A.; SANTOS, R.C.; SORATTO, D.N. Propriedades de painéis aglomerados fabricados com partículas de eucalipto (Eucalyptus urophylla), Paricá (Schizolobium amazonicum) e vassoura (Sida spp.). Cerne, v.18 n.4 p. 623-630, 2012. 
BOFF, V. L.; MELLO, A. H.; MANESCHY, Rosana Quaresma. Fungos micorrízicos arbusculares em mudas de Paricá: colonização, dependência e relações com o desenvolvimento das plantas. Enciclopédia Biosfera, Centro Científico Conhecer - Goiânia, v.10, n.18, 2014.

BRITO; V. N.; TEllecheA, F. R. F.; HeITOR, L. C.; FREITAS, M. S. M.; MARTINS, M. A. Fungos micorrízicos arbusculares e adubação fosfatada na produção de mudas de Paricá. Ciência Florestal, v. 27, n. 2, 2017.

COLODETE, C. M.; DOBBSS, L. B.; RAMOS, A.C. Aplicação das micorrizas arbusculares na recuperação de áreas impactadas. Revista Natureza on line, v. 11, n. 1, p. 31-37, 2014.

DUTRA, F. V.; CARDOSO, A. D.; DA SILVA, R. M.; DA SILVA, L. R.; MORAIS, O. M.; RAMPAZZO, M. C. Morfobiometria de frutos e sementes de Schizolobium amazonicum Huber ex Ducke. Agropecuária Técnica, v. 38, n. 2, p. 58-64, 2017.

FONSECA, E. D. P.; VALÉRI, S. V.; MIGLIORANZA, É.; FONSECA, N. A. N.; COUTO, L. Padrão de qualidade de mudas de Trema micrantha (L.) Blume, produzidas sob diferentes períodos de sombreamento. Revista Árvore, v. 26, n. 4, p. 515-523, 2002.

GOMES, J.M.; COUTO, L.; LEITE, H.G.; XAVIER, A.; GARCIA, S.L.R. Parâmetros morfológicos na avaliação da qualidade de mudas de Eucalyptus grandis, Revista Árvore, v.26, n.6, p.655-664, 2002.

GOMES, J. M.; PAIVA, H. P. Viveiros florestais (propagação sexuada). Viçosa, MG: Universidade Federal de Viçosa, 116p, 2004.

IWAKIRI, S.; VARGAS, C. A.; PARCHEN, C. F. A., WEBER, C.; BATISTA, C. C.; GARBE, E. A.; PRATA, J. G. Avaliação da qualidade de painéis compensados produzidos com lâminas de madeira de Schizolobium amazonicum. Floresta, v. 41, n. 3, p. 451-458, 2011.

JOSÉ, A. C.; DAVIDE, A. C.; OLIVEIRA, S. L. Efeito do volume do tubete, tipo e dosagem de adubo na produção de mudas de aroeira (Schinus terebinthifolia Raddi). Agrarian, v.2, n.3, p.73-86, 2009.

KIERS, E.T; VAN DER HEIJDEN, M.G.A. Mutualistic stability in the arbuscular mycorrhizal symbiosis: exploring hypotheses of evolutionary cooperation. Ecology, v. 87, n. 7, p. 1627-1636, 2006.

LACERDA, K.A.P.; SILVA, M. M. S.; CARNEIRO, M.A.C.; REIS, E.F.; SAGGIN JÚNIOR, O.J. Fungos Micorrízicos Arbusculares e Adubação Fosfatada no Crescimento inicial de seis espécies arbóreas do Cerrado. Cerne, v. 17, n. 3. p. 377-386, 2011.

LiSBOA, A. C.; SANTOS, P. S. D.; OliVEIRA NETO, S. N. D.; CASTRO, D. N. D.; ABREU, A. H. M. D. Effect of volume of tubes on the production of seedlings of Calophyllum brasiliense and Toona ciliata. Revista Árvore, v. 36, n. 4, p. 603-609, 2012.

LUCENA, V. B.; RAIMAM, M. P.; CARDOSO, N. A.; ALBINO, U. B. Influência de fungos micorrízicosarbusculares em Paricá (Schizolobium amazonicum) cultivado no estado do Pará. Pesquisa Florestal Brasileira, Colombo, v. 33, n. 75, p. 235-241, 2013.

PEREIRA, M. S. F.; HADDAD, L. S. A. M.; BAZZOLLI, D. M.S.; KASUYA, M. C. M. Micorriza arbuscular e a tolerância das plantas ao estresse. Revista Brasileira de Ciência do Solo. v.36, n.6 p.1663-1679, 2012.

SAMARÃO, S. S.; RODRIGUES, L. A.; MARTINS, M. A.; MANHÃES, T. N.; ALVIM, L. A.M. Desempenho de mudas de gravioleira inoculadas com fungos micorrízicos arbusculares em solo não-esterilizado, com diferentes doses de fósforo. Acta Scientiarum. Agronomy, v. 33, n. 1, 2011.

SANQUETTA, C. R.; DALlA CORTE, A. P.; BEHLING, A.; CARDORI, G. C.; COSTA JUNIOR, S.; RUZA, M. S. Crescimento de área e índice de área foliar de mudas de Eucalyptus dunii Maiden. Em diferentes condições de cultivos. Revista Biociências, v. 20, n. 2, p. 82-89, 2014.

SANTOS, J.G.D.; SIQUEIRA, J.O.; MOREIRA, F. M. S. Eficiência de fungos micorrízicos arbusculares isolados de solos de áreas de mineração de bauxita no crescimento inicial de espécies nativas. Revista Brasileira de Ciência do Solo, v.32, n.1, p.141-150, 2008.

SOARES, A.C.F.; GARRIDO, M.S.; AZEVEDO, R.L.; MENDES, L.N. GRAZZIOTTI, P.H. Produção de mudas de ipê roxo inoculadas com fungos micorrízicos arbusculares. Magistra, v.15, n.2, p. 123-127, 2003.

FLORESTA, Curitiba, PR, v. 49, n. 4, p. 651 - 660, out/dez 2019.

Andrade, A. V. N. et.al.

ISSN eletrônico 1982-4688

DOI: $10.5380 /$ rf.v49 i 4.57186 
SOARES, A. C. F.; SOUSA, C.S., GARRIDO, M. S., LIMA, F. S. Fungos micorrízicos arbusculares no crescimento e nutrição de mudas de jenipapeiro. Revista Ciência Agronômica, v. 43, n. 1, 2012.

SUGAI, M.A.A.; COLLIER, L.S.; SAGGIN JÚNIOR, O.J. Inoculação micorrízica no crescimento de mudas de angico em solo de cerrado. Bragantia, Campinas, v. 70, n. 2, p.416-423, 2010.

WENDLING, I.; ADAMS, D.; TANNER, L.J.; FRACARO, L.C.; SANTOS, V.O.C.; VEIGA, J.N. Rotinas e procedimentos adotados no laboratório de propagação de espécies florestais (LPEF) da EMBRAPA Florestas. Colombo: EMBRAPA Florestas, 2011. 